\title{
The role of PTH in mouse skin tumorigenesis
}

\author{
Kazuhiro Okumura, Megumi Saito and Yuichi Wakabayshi* \\ Department of Carcinogenesis Research, Division of Experimental Animal Research, Chiba Cancer Center Research Institute, Japan
}

Vitamin D and calcium are known to regulate differentiation and proliferation of keratinocytes; they may potentially have roles in suppressing carcinogenesis in squamous epithelium [1]. Indeed, the importance of the vitamin $\mathrm{D}$ receptor (VDR) in regulating cellular proliferation and differentiation was verified when the skin of mice lacking the VDR was reported to be susceptible to tumor formation [1]. In addition, knockout of the calcium sensing receptor in addition to VDR accelerated the development of skin tumors [2]. However, the role of Parathyroid Hormone (PTH) in tumorigenesis is yet to be elucidated. PTH is a classical endocrine hormone that was first identified more than 80 years ago as a key regulator of blood calcium levels [3]. Serum PTH is a sensitive indicator of calcium and vitamin $\mathrm{D}$ deficiency.

Recently it was reported that serum intact-PTH (iPTH) and a genetic polymorphism in $P$ th are important for skin tumor resistance [4]. Higher iPTH levels were detected in sera from cancer-resistant MSM/Ms mice compared with susceptible FVB/NJ mice. Skin carcinogenesis experiments with MSM-BAC transgenic mice $\left(P t h^{\mathrm{MSM}}\right.$ $\mathrm{Tg})$ and $P$ th heterozygous knockout mice $\left(P t h^{+/}\right)$showed the higher amounts of iPTH in sera conferred stronger resistance to skin tumors.
However, the differences was not detected in either serum calcium or 1,25(OH) ${ }_{2} \mathrm{D}$ among MSM, $P t h^{\mathrm{MSM}}-\mathrm{Tg}$ and $P t h^{+/-} \mathrm{KO}$ mice. These results indicate PTH confers resistance to skin tumors independently from serum calcium and vitamin D. In this report, it is also shown that PTH increases intracellular calcium in keratinocytes and promotes their terminal differentiation. Taken together, these data suggest that serum iPTH could serve as a prevention marker of skin cancer and a target for new therapies.

\section{References}

1. Zhang H, Lu H, Shrestha C, Feng Y, Li Y, et al. (2015) In serum, higher parathyroid hormone but not lower vitamin D is associated with oral squamous cell carcinoma. Curr Oncol 22: e259-e263. [Crossref]

2. Bikle DD (2011) The vitamin D receptor: a tumor suppressor in skin. Discov Med 11 7-17. [Crossref]

3. Murray TM, Rao LG, Divieti P, Bringhurst FR (2005) Parathyroid hormone secretion and action: evidence for discrete receptors for the carboxyl-terminal region and related biological actions of carboxyl- terminal ligands. Endocr Rev 26: 78-11. [Crossref]

4. Okumura K, Saito M, Yoshizawa Y, Munakata H, Isogai E, et al. (2017) The parathyroid hormone regulates skin tumour susceptibility in mice. Sci Rep 11: 11208.
Copyright: (C2018 Okumura K. This is an open-access article distributed under the terms of the Creative Commons Attribution License, which permits unrestricted use, distribution, and reproduction in any medium, provided the original author and source are credited.
*Correspondence to: Yuichi Wakabayshi, Department of Carcinogenesis Research, Division of Experimental Animal Research, Chiba Cancer Center Research Institute, 666-2 Nitonacho Chuouku, Chiba 260-8717, Japan, E-mail: yuichi_wakabayashi@chiba-cc.jp

Received: March 15, 2018; Accepted: April 03, 2018; Published: April 06, 2018 